\title{
Hepatitis E Virus
}

\author{
Arbeitskreis Blut, Untergruppe «Bewertung Blutassoziierter Krankheitserreger»
}

\section{Current Knowledge about the Pathogen}

\subsection{Characteristics of Hepatitis $E$}

First indications of hepatitis $\mathrm{E}$ as a distinct disease, which differs from hepatitis A, were found in 1980 when sensitive and specific detection systems for hepatitis A virus (HAV) first became available and hepatitis epidemics were examined in India. Epidemiologic studies up to that time pointed to the fact that these hepatitis infections with clinically very similar course were caused by HAV pathogens transmitted by the faecal-oral route. The experimental proof that a second virus transmitted by the faecal-oral route, which was later called hepatitis E virus (HEV), was provided in 1983 by the transmission studies of Balayan et al. [1]. In these experiments, HAVimmune voluntary individuals were infected with stool suspensions from patients with a hepatitis A-like disease which occurred in Tashkent, Uzbekistan. Spherical virus-like particles, $27-30 \mathrm{~nm}$ in diameter, could be isolated from the stools of the experimentally infected persons, which formed a band in the $\mathrm{CsCl}$ gradient at a density of $1.35 \mathrm{~g} / \mathrm{cm}^{3}$. These particles could be detected by immuno-electron microscopy (IEM) both in the pre-clinical (as from the 27th day post infection (dpi)) and in the post-clinical phase (45 dpi, onset of the disease approximately $36 \mathrm{dpi}$ ) (fig. 1).

Up to 1990, IEM and the inoculation of monkeys were the only diagnostic methods for the detection of HEV infections and their differentiation from HAV. In 1991, Reyes et al. [2] succeeded in cloning the genome. This opened new paths for the development of diagnostic methods for serological and molecular detection of HEV infections. HEV was first categorised as part of the Caliciviridae family, based on its morphological properties. Sequence analysis, however, revealed that the genome structure of $\mathrm{HEV}$ is significantly distinct from this virus family. Therefore, HEV is today classified as the so far only representative of the hepevirus genus in the new family of Hepeviridae.
HEV is a small non-enveloped, single-stranded icosaedric virus with a diameter of approximately $32-34 \mathrm{~nm}$. The capsid of the virus probably consists of one single protein. The genome is single-stranded positive-sense with a size of $7.2 \mathrm{kbp}$. It is flanked by non-encoding regions, polyadenylated at the $3^{\prime}$ end, and bears a $\mathrm{m}^{7} \mathrm{G}$-cap at the $5^{\prime}$ end. The genome itself encodes for three overlapping open reading frames (ORF 1-3). Hepeviruses have the feature that the ORF 2 with a length of $2 \mathrm{kbp}$ located at the $3^{\prime}$ end encodes for the capsid protein. It is especially this characteristic that makes the HEV virus distinct from the calicivirus, in which the sequence encoding for the capsid is located at the 5' end. ORF 1 with a length of approximately $5 \mathrm{kbp}$ is located at the $5^{\prime}$ end and encodes for the nonstructural proteins involved in RNA replication: RNA-dependent RNA polymerase, guanylyl and methyl transferases, helicase and a papain-like protease. ORF 3 with a length of $372 \mathrm{bp}$ overlaps at the $3^{\prime}$ end with the first $331 \mathrm{bp}$ from ORF 2 and at the 5 ' end with ORF 1 . ORF 3 encodes for a small immunogeneic phosphoprotein with a size of not more than 123 amino acids.

Based on phylogenetic analyses, the isolates examined up to now are classified into four different genotypes which have different world-wide distributions [3]. For genotype 1 the Burma isolate represents the prototype, for genotype 2 the Mexican isolate, for genotype 3 the USA isolate, and for genotype 4 the Chinese isolate. The different genotypes are then further grouped into different genetic subtypes. Serologically, HEV seems to behave in a uniform manner, as neutralisation studies in the cell culture and protection studies with different genotypes in infection studies have shown [4].

Various studies provide evidence that HEV replicates in hepatocyte culture of humans and macaques. For this purpose, cell cultures were infected with HEV from stool suspensions. In such in vitro studies, Emerson et al. [5] were able to show that approximately half the $\mathrm{HEV}$ infectiveness was inactivated after heat treatment at $45-50{ }^{\circ} \mathrm{C}$ for $1 \mathrm{~h}$ and almost the entire $\mathrm{HEV}$ infectiveness at $56^{\circ} \mathrm{C}$. In addition, the authors were able

\section{KARGER}

Fax +49 7614520714

Information@Karger.de

www.karger.com 
to show that, although different HEV isolates showed different degrees of heat stability, all isolates studied were sensitive to treatment at $60{ }^{\circ} \mathrm{C}$ for $1 \mathrm{~h}$. In contrast to this, only half of the HAV could be inactivated when treated at $60{ }^{\circ} \mathrm{C}$ for $1 \mathrm{~h}$ and lost its infectiveness only after heat treatment at $66{ }^{\circ} \mathrm{C}$. These findings thus revealed that HEV was more sensitive to heat than HAV [5]. Tanaka et al. [6] completed the thermostability studies of $\mathrm{HEV}$ with cell culture-adapted $\mathrm{HEV}$. Heat treatment of $\mathrm{HEV}$ at $90{ }^{\circ} \mathrm{C}$ for $1 \mathrm{~min}$ or at $70{ }^{\circ} \mathrm{C}$ for $10 \mathrm{~min}$ inactivated $\mathrm{HEV}$ entirely. Incubation of $\mathrm{HEV}$ suspensions at $56{ }^{\circ} \mathrm{C}$ for $30 \mathrm{~min}$ reduced the titre in comparison to treatment at $25^{\circ} \mathrm{C}$.

\subsection{Infection and Infectious Diseases}

The course of HEV infections is similar to that of HAV infections. As a rule, acute HEV infection is self-limiting with a low death rate, which is, however, higher $(0.5-4 \%)$ than that of the HAV infection (approximately $0.2 \%$ ) [7]. HEV is usually transmitted by the faecal-oral route and is excreted in the stool for 3-4 weeks. In some patients, an excretion period of up to 120 days could be observed using PCR [8]. It is assumed that HEV first replicates in the intestinal duct and then reaches the liver via the blood vessels. There, replication of the virus takes place in the cytoplasm of hepatocytes. The virus is then excreted into the stool and the blood via the gall. The incubation period measured by the increase in transaminases can be between 3 and 8 weeks. In the acute incubation phase up to the late phase, the virus is excreted via the stool in high quantities [1]. Experimental oral infections of humans showed that viraemia was first detectable between the 22nd and the 28th dpi, approximately 1 week before the occurrence of symptoms $[1,9]$. Symptoms of the disease then occurred between the 30 th and the 36th dpi. The peak of the transaminases was observed at approximately the same time as the appearance of the first antibodies. Histologically, focal necroses and apoptosis of cells are found in the liver. Whether the observed alterations are caused by the virus itself or by the immune response is unclear, since only minor signs of inflammation could be detected [10]. Comparable courses of infection were also observed in experimental transmissions of HEV to primates $[11,12]$.

Similarly to hepatitis A, an IgM and an IgG response can be measured at approximately the time of the occurrence of symptoms in the acute HEV infection.

HEV infections during pregnancy have a high percentage of serious outcomes, accompanied by a high mortality rate of approximately $20 \%$. The mortality rate in men and non-pregnant women is $0.5-4 \%[7,10,13,14]$. In addition to the serious liver failure which is observed in particular in pregnant women in their third trimester, encephalopathies and disseminated intravascular consumptive coagulation disorders can occur.

In the past few years, there have been an increasing number of

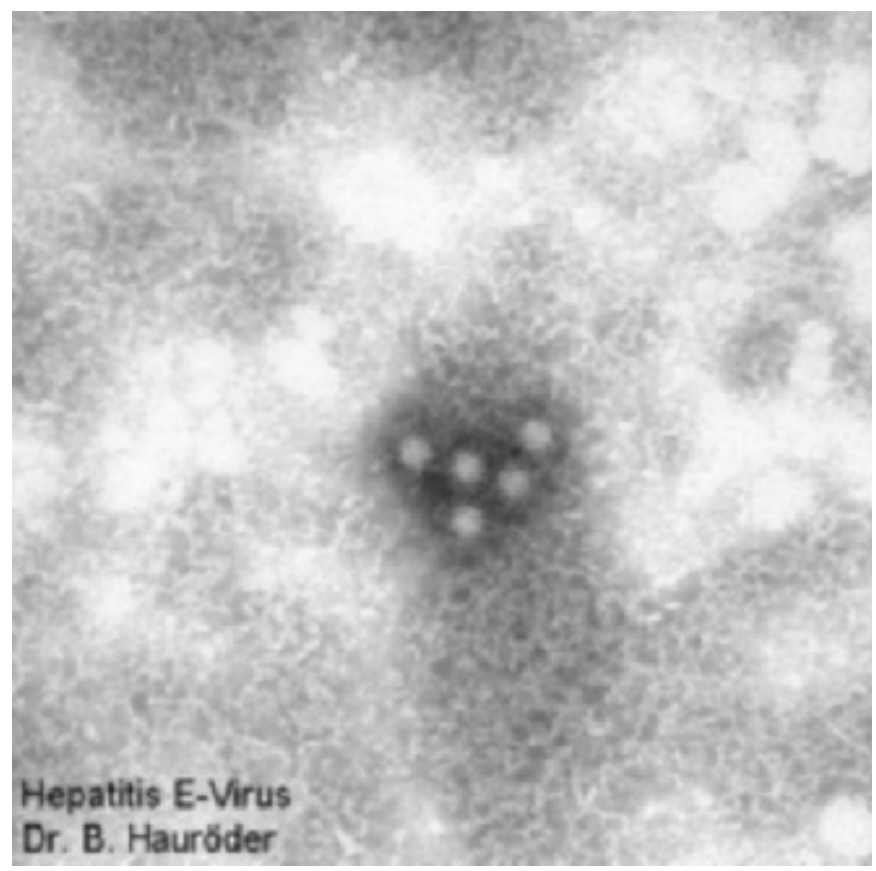

Fig. 1. Electron microscope photo of an immune aggregate of $\mathrm{HEV}$ isolated from the gall of an experimentally infected macaques. The infectious $\mathrm{HEV}$ was isolated from the faeces of an individual with HEV. The monkeys were infected orally. We thank Dr. Bärbel Hauröder, Zentrales Institut des Sanitätsdienstes der Bundeswehr Koblenz (Central Institute of the Paramedic Services of the Bundeswehr (German army) at Koblenz, Germany).

reports about HEV infections with sub-clinical course $[15,16]$. Increased levels of transaminases may act as infection markers. In this phase, HEV genome is detectable in the blood in a high percentage of the infected individuals. More or less simultaneously, an increase in the HEV-specific IgM and IgG antibody responses are observed. Transmissions of HEV by non-inactivated blood products from such donors have been reported from various countries [17-21].

\subsection{Epidemiology}

Acute hepatitis E is a very frequent cause of hepatitis acquired by the faecal-oral route world-wide. For a long time, $\mathrm{HEV}$, the causative agent of this disease, was considered as a human-specific pathogen. As far as geographic distribution is concerned, one distinguishes between those regions, where HEV occurs endemically, and those where it is sporadic [22]. In this context, Southeast and Central Asia, the Middle East, Africa and Central America are considered as endemic areas. In these regions, pronounced epidemics have been observed in the past few decades, which were frequently caused by contaminated drinking water, but isolated sporadic cases of HEV infection have also been reported. 
Table 1. Notifications of HEV infections in compliance with the IfSG (Infection Protection Act) (Source: Robert Koch-Institut)

\begin{tabular}{lll}
\hline Year & \multicolumn{2}{l}{ Cases of HEV reported in Germany } \\
\cline { 2 - 3 } & total & acquired in Germany \\
\hline 2001 & 31 & 11 \\
2002 & 17 & 7 \\
2003 & 33 & 10 \\
2004 & 53 & 21 \\
2005 & 54 & 23 \\
2006 & 51 & 23 \\
\hline
\end{tabular}

In the industrialised countries of Europe and America, HEV infections as a rule only occurred in travellers who had previously stayed in endemic areas. In the past few years, however, more and more reports have been published stating that sporadic hepatitis $\mathrm{E}$ also occurs in non-endemic areas, i.e. industrialised countries, without any connection with travelling to classic endemic areas [23, 24].

Most of the serious HEV infections in Asia and Africa are caused by genotype 1 while genotype 2 predominates in Mexico, Egypt, Nigeria, and Namibia. Genotype 3 has been observed in Asia, America and Europe as well as in New Zealand. The recently newly described genotype 4 has up to now been observed mainly in Asia [3,25]. According to findings established, genotypes 1 and 2 have mainly been found with disease in humans in the respective endemic areas. Genotypes 3 and 4, however, have been found both in humans and in animals, especially domestic and wild pigs [25].

Animals, especially pigs, are regarded as the source of the infectious pathogens for humans in industrialised countries. Hepatitis $\mathrm{E}$ is therefore to an increasing extent considered to be a zoonosis. HEV was first detected successfully in a pig in the USA in 1997 [26]. A high HEV prevalence rate is shown in pigs in nearly all regions of the world [22]. Evidence for this could be provided by serological, virological and molecular detection methods. In addition, the close relationship of isolates from humans and pigs in the respective regions could be shown by phylogenetic analyses of the virus genomes.

Experimental infections in primates and pigs with HEV, and in pigs with human isolates, support the hypothesis that hepatitis E is a zoonosis [27]. Apart from pigs, HEV was detected in various other species such as rats, dogs and birds. It has so far been unclear which role these species play in the transmission to humans.

Sporadic outbreaks of HEV infection in Japan were attributed to the consumption of insufficiently cooked or raw pork, venison or boar meat [28]. This assumption has been supported by studies performed by Feagins et al. [29] who were able to isolate infectious HEV from commercial pork liver in the USA. Studies on the prevalence of HEV infections both in humans and in pigs were performed in various European countries. Studies in Spain have shown that HEV is very widespread in pig populations and that an age-dependent increase in the seroprevalence can be observed [30]. Furthermore, HEV could be detected in the faeces of the animals by NAT/PCR in the age group of $8-12$ weeks. Comparable results were also obtained when studying pig populations in the Netherlands, where HEV genome could be detected in the faeces in a high percentage of the fattening farms [31]. A close relationship between human and porcine $\mathrm{HEV}$ was reported from the UK $[32,33]$.

Altogether, only few studies are available on the prevalence of HEV infections in humans. High antibody prevalence with approximately $13 \%$ has been reported from Sweden and lower antibody prevalence from France and Spain (approximately $3 \%$ ) $[34,35]$. In various studies, persons with close contact to pigs such as pig breeders and animal traders showed a higher seroprevalence compared with the general population [36,37]. This indicates that pigs can be regarded as one of the transmitters of HEV to humans.

Tests of urban sewage water in various industrialised countries showed that for example in Barcelona (Spain), Nancy (France), and Washington, DC (USA) HEV genome could be detected, pointing to the fact that $\mathrm{HEV}$ infections in these countries may frequently take a subclinical course and remain undetected, since no simultaneous clinical HEV infection were observed [38]. The extent to which HEV is transmitted by insufficiently purified sewage water in industrialised countries remains unclear.

Only little information is available on the prevalence and incidence of HEV infections in Germany. It has been discussed for a long time whether acute hepatitis E only occurs in travellers returning from endemic areas [39]. More recent studies have revealed that HEV infections can also be acquired in Germany, and can lead to acute courses of disease [40, 41]. Data obtained on the basis of the requirement to notify hepatitis infections in compliance with the IfSG (Infektionsschutzgesetz; Infection Protection Act) show that approximately half of the German hepatitis E cases notified were acquired in Germany, and that there was no connection with travels to endemic areas (table 1). The few HEV cases which have so far been phylogenetically analysed in Germany confirm the close relationship to pig isolates found in various other European countries [41].

\subsection{Detection Methods and Their Significance}

Up to now it has not been possible to grow HEV routinely in cell culture for diagnostic purposes. Before molecular detection methods were established, virus detection was performed in the faeces by means of electron microscopy or IEM.

Today, HEV can be reliably detected using PCR in the acute phase from faeces or blood. The nucleic acid detection method and sequence analyses of the amplificates, however, have shown that there is a great number of genetic HEV variants. The sensitivity of the PCR therefore depends on the homology of the primer with the isolate to be examined. The extent to 
which real-time PCR and nested PCR systems are suitable for the detection of all 4 genotypes known up to now requires further examination [42-44]. Detection of viral RNA confirms the presence of active HEV.

The extent to which antigen detection systems are suitable for the detection of viraemia can only be clarified by further development of experimental antigen detection systems [45].

Serological detection systems for diagnosing an HEV infection still represent the method of choice. Commercial antibody detection systems (ELISA) are available for the detection of $\mathrm{IgG}$ and/or IgM antibodies. These systems are based on recombinant ORF 2 and ORF 3 proteins expressed or synthetic peptides. Immunoblots based on recombinant proteins can be used for confirming the reactive sera.

At the time of first detection of HEV antibodies and the presence of clear clinical symptoms of hepatitis, an HEV infection is likely, if hepatitis A, B and C can be excluded. To confirm, a second sample should be drawn 8-10 days later, in order to provide evidence for the increase in antibodies. In approximately $90 \%$ of the acute HEV infections, IgM antibodies can be detected 1-4 weeks after occurrence of the clinical symptoms. As a rule, these IgM antibodies can no longer be detected 3 months after the onset of the disease. More recent findings show, however, that anti-HEV IgA antibodies may provide a reliable way of detecting an acute HEV infection [24, 46].

The postulation that a stay in an endemic area of HEV should be one of the criteria for a suspected hepatitis E diagnosis can no longer be maintained based on the current state of knowledge. Studies on the spread of HEV in non-epidemic areas give rise to the assumption that HEV infections may take on an asymptomatic or subclinical course in industrialised countries.

\section{Blood and Plasma Donors}

\subsection{Prevalence and Incidence in Donor Populations}

Data on the prevalence of HEV infections in blood and plasma donors and/or in the general population are not available in Germany. In Japan, a country in which only sporadic cases of $\mathrm{HEV}$ have been reported, studies have been performed in 6,700 blood donors with elevated transaminases [16]. HEVspecific antibodies could be determined in $7.1 \%$ of the individuals studied. In $9(0.13 \%$ of the samples studied $)$ of these blood donors, HEV RNA could be detected, with 6 of these donors also showing anti-HEV IgM and/or IgA antibodies. Three donors were only HEV genome-positive. The authors rule out that in Japan, a country with a comparatively low number of reported acute HEV infections, more subclinical cases occur than expected. It must, however, be assumed that the prevalence in the donor cohort is comparable with that of the overall population. These results confirm previous reports from Japan that HEV was detected in blood donors by means of PCR [47]. To what extent antigen detection systems are suitable for detecting viraemia can only be clarified by the further development of experimental antigen detection systems [45]. Studies of blood donors in HEV-endemic areas such as India give rise to the assumption that in such countries there is an increased risk of transfusion-transmitted HEV [48].

Investigations performed on small random samples of blood donors in the Netherlands showed that $0.4 \%$ of the donations were HEV antibody-positive [49], while the number in Spain was $2.8 \%$ of the donations tested [34]. In France, a prevalence of $3.2 \%$ was determined in blood donors, with only 20-30 autochthonous cases reported annually in that country [35].

In a multi-centre study in 1993, data were collected on the prevalence of HEV infections in Germany [50]. In this study the prevalence of $0.5 \% \mathrm{HEV}$ antibody-positive donors determined is possibly too low, since the sensitivity of the tests has meanwhile been improved. The number of autochthonous hepatitis E cases reported for Germany is comparable with that of France so that it cannot be ruled out that HEV seroprevalence in Germany is similar to that in France.

\subsection{Definition of Exclusion Criteria}

The guidelines of the Bundesärztekammer (German Medical Association) and the Paul-Ehrlich-Institut (PEI) [51, 52] form the basis for the exclusion criteria for blood donors. Individuals who are or have been diseased with infectious hepatitis of unclear aetiology should be permanently deferred from donating blood. These guidelines, however, do not deal explicitly with HEV infection. In the event of confirmed or suspected hepatitis $\mathrm{E}$, the donors must be deferred from the donation. This also applies to suspected acute infection of persons who are in a close contact with the donor. Status after overcoming hepatitis E, or determination of anti-HEV IgG antibody confirming recovery from hepatitis $\mathrm{E}$, is not an exclusion criterion. This recommendation is equivalent to the procedure for individuals who recovered from HAV infection [53].

\subsection{Donor Testing and Significance}

Donor testing for HEV genome by means of PCR or antibody detection (IgM and/or $\operatorname{IgA}$ as early infection markers) is possible in principle. Based on the findings available up to now on the epidemiology of HEV infections in Germany, donor testing for virus genome of $\mathrm{HEV}$ or $\mathrm{HEV}$-specific antibodies is not considered necessary.

\subsection{Donor Interviews}

The volunteer who intends to donate blood is asked whether he/she has had a history of hepatitis before each donation, in 
accordance with the guidelines of the Bundesärztekammer and the PEI. Recovery from a hepatitis E infection in the history is not a criterion for a general donor deferral.

\subsection{Donor Information and Counselling}

Since no special examination for HEV markers is performed, no HEV-specific donor information is necessary. If there are signs of hepatitis infection of unclear origin, HEV can be detected by using serological or molecular methods.

\section{Recipients}

\subsection{Prevalence and Incidence of Blood-Associated Infections and Infectious Diseases in Recipient Populations}

Neither donor- nor recipient-specific information is available on the prevalence and incidence of HEV infections in Germany. It can, however, be assumed that there is a prevalence for antibodies against HEV in these collectives which corresponds to that of the general population, as also described for other European countries.

Studies, in particular in Japan, give rise to the assumption that transmissions of HEV by blood transfusion can be observed. Retrospective data collections, particularly in transfusion recipients displaying increased transaminase values or a serious hepatitis infection, showed that part of these patients had acquired an HEV infection due to this transfusion [19, 34, 48]. Recently, HEV transmissions by transfusion have also been reported from Europe [20,21]. Haemodialysis patients seem to have an increased infection risk [54]. To what extent this is due to the administration of blood products or has a different cause is unclear. Only few studies on haemophiliacs have been described in the literature $[49,55,56]$; none of these studies pointed to a recognisable transmission risk for HEV by coagulation factors.

\subsection{Immune Status (Resistance, Existing Immunity, Immune Response, Age, Exogenous Factors)}

No results are available on the prevalence rate among the recipients of blood and blood products in Germany.

\subsection{Severity and Course of the Disease}

Reports on HEV infections by contaminated blood products give rise to the assumption that the course of infection is comparable to that of a natural HEV infection [19]. Persisting infection following transfusion was reported in a T-lymphoma patient who was also receiving chemotherapy [57].

\subsection{Therapy and Prophylaxis}

Studies on possible passive immunisation have been reported [58], and the administration of anti-HEV immunoglobulin products as post-exposure prevention, especially for pregnant women, has been discussed.

The development of a vaccine has so far been hampered because HEV has been difficult to replicate in cell culture and because vaccines on the basis of inactivated viruses or nonpathogenic isolates have therefore not been available. The focus of vaccine development was therefore on DNA technology or recombinant proteins [59-63]. One candidate for a DNA vaccine is currently undergoing phase II of a clinical study [63].

\subsection{Transmissibility}

Retrospective studies by Arankalle and Chobe [17, 48] give reason to presume that $\mathrm{HEV}$ can be transmitted by blood transfusions in regions where it is endemic. Transfusion-associated HEV transmissions were reported from Saudi-Arabia, a country where HEV occurs endemically [18]. First reports on transfusion-associated HEV infections from Japan, which has not been rated as an endemic region, were published almost simultaneously $[19,54]$. In one case, it could be demonstrated that transmission occurred by transfusion of FFP, but not by the corresponding red blood cell concentrate from the same donor [19].

A case of transfusion-associated HEV transmission has recently been reported also in Europe in a region in which acute hepatitis E occurs only sporadically. In the UK, a patient was infected by a red blood cell concentrate. This concentrate only contained small amounts of plasma from the donor. Another patient who had received a platelet concentrate from the same donation was not infected [20]. A child in France was also infected by a red blood cell concentrate [21]. Both the donor in the UK and the donor in France had acquired their HEV infection in their own countries. Both blood donors were HEV RNA-positive at the time of the donation but did not show elevated transaminases.

As can be concluded from the few more exactly scrutinised HEV transmission cases, HEV can be transmitted by non-inactivated blood components. It can be assumed that this is the case especially during the viraemia phase (approximately 20-50 days following infection) by cell-free virus in the plasma.

\subsection{Frequency of Administration, Type and Amount of Blood Products}

No conclusions can be drawn from the few reported cases of transmission as to an increased risk of an HEV infection by frequent treatment with non-inactivated blood components, 
even though several of the patients affected received transfusions from multiple sources.

\section{Blood Products}

\subsection{Infectious Load of the Starting Material and Test Methods}

Up to now, no tests have been performed on the viral HEV burden of the starting material. In principle, such a test on these materials for HEV genome would be possible by means of NAT.

\subsection{Methods for Removal and Inactivation of the Infectious Agent}

There are no investigations on the removal and inactivation of $\mathrm{HEV}$ in blood products. In the past few years, animal caliciviruses such as the feline calicivirus ( $\mathrm{FeCV}$ ) were used as model viruses for the validation of inactivation methods. To what extent these model systems reflect the stability of HEV is unclear.

\subsection{Feasibility and Validation of Procedures for Removal/ Inactivation of the Infectious Agent}

In general, procedures of inactivation and/or removal of nonenveloped viruses during the preparation of plasma products are more limited than those for enveloped viruses. The assessment of the capacity of methods of inactivating and/or removing HEV is currently based on the experience with non-enveloped model viruses from other virus groups, especially from FeCV. Studies with HEV itself are available only to a very limited extent, since culturing adapted HEV isolates is difficult, and the cell culture systems are available to only a limited extent. Whether these systems are suitable for validating production steps during the manufacture of blood products remains to be examined.

In the past few years, studies on the thermostability of HEV were carried out. Compared with HAV, HEV proved to be less thermostable [5]. However, in these studies, no exact kinetics of inactivation was displayed, and no stabilisers applied in the production of coagulation factors were investigated.

Preliminary studies show an effective inactivation of $\mathrm{FeCV}$ at $60{ }^{\circ} \mathrm{C}$ in liquid phase in the presence of such stabilisers (Blümel et al., unpublished; Gröner et al., unpublished). However, to what extent FeCV reflects the heat stability of HEV is unknown. The stability of FeCV and HEV during dry heat application is also unknown.

Stability at low $\mathrm{pH}$ values ( $\mathrm{pH} 3.7-4.2)$ as it is used in the production of antibody preparations is also unknown. Extrapolation from the inactivation data from other non-enveloped viruses is difficult. HAV and animal parvoviruses are usually stable under these conditions.

It can be assumed that filtration methods (virus filter, nanofilter) remove HEV effectively from the product if filters were used which remove smaller viruses such as HAV or parvoviruses. Such filters are often used in the production of factor IX or partly in the production of immunoglobulin preparations. For the filtration of complex coagulation factors, however, only filters with medium diameters of 35-50 nm are often used. In this case the retention of HEV or calicivirus is limited and may strongly depend on specific filters or production conditions. This should be evaluated on a case-to-case basis.

The risk of an HEV transmission by plasma products is currently estimated to be low since steps have been introduced for most of the products (except for SD-treated plasma) which are considered to be at least partly effective in activating or removing HEV. A more accurate assessment of the risk, however, is currently not possible since important data on the epidemiology, the HEV burden in the plasma pool, the prevalence of antibodies in plasma donations and/or plasma pools, and on the inactivation/removal of HEV during the manufacturing process is not available. A product-specific examination of the manufacturing procedures for inactivation/removal of $\mathrm{HEV}$ is required in those cases in which the data available on non-enveloped model viruses cannot clearly be transferred to HEV.

The effectiveness of the inactivation methods developed for plasma and cellular blood products (treatment with amotosalen, riboflavin, or methylene blue) is currently unknown. A risk of HEV transmission by blood components can therefore currently not be ruled out in general.

\section{Assessment}

For a long time, hepatitis E was considered as travel-associated disease. Today, however, evidence has been found that HEV infections not only occur in classical endemic areas with a low standard of hygiene but also in industrialised countries. In the classical endemic areas, particularly the HEV genotypes 1 and 2 have been found. The pathogen is transmitted by the faecal-oral route via contaminated water and food. In non-endemic areas, mainly sporadic HEV infections of the genotypes 3 and 4 are observed. Animals, mainly pigs, provide the reservoir for these two genotypes. Based on the current state of knowledge, pig populations world-wide show a very high HEV infection rate. Phylogenetically closely related viruses are found in industrialised countries in humans with HEV infections and in pigs. Although only low numbers of autochthonous human HEV infections have been reported in industrialised countries, the seroprevalence is relatively high, reaching approximately $13 \%$, e.g. in Sweden.

These findings give rise to the assumption that a considerable number of $\mathrm{HEV}$ infections in industrialised countries shows a 
subclinical course, and that these infections can only be detected by the identification of the HEV genome and/or seroconversion. It has been shown that not only individuals during the incubation and the clinical phase of hepatitis E, but also subclinically infected individuals display $\mathrm{HEV}$ viraemia, and that the virus can also be transmitted by blood donations from such donors.

The risk of HEV transmission by blood products has not been sufficiently examined in Germany. Data are missing on the prevalence of $\mathrm{HEV}$ infections in the population, in the blood donor collective, and in individuals with a higher risk of exposure for HEV such as veterinarians, pig breeders, pig fatteners, and the staff of abattoirs and butcher businesses. Moreover, there is no information on the prevalence and incidence of HEV in the animal reservoir for Germany, particularly in pig populations. The current state of knowledge is not sufficient to judge the necessity of blood donor testing for HEV genome or HEV antibodies. Based on clinical experience, these tests do not seem to be necessary considering the current epidemiological situation. However, there is a major need for research, especially for collecting epidemiological data, and with regard to targeted look-back tests for transfu- sion-associated HEV infection in transfusion recipients and the corresponding donors.

This paper was completed on June 22,2007, and approved by the German Advisory Committee Blood (Arbeitskreis Blut) on October 1, 2007. It was compiled by the members of the subgroup 'Assessment of Pathogens Transmissible by Blood' of the German Advisory Committee Blood (Arbeitskreis Blut):

\section{Prof. Dr. Georg Pauli}

Dr. Johannes Blümel

Prof. Dr. Reinhard Burger

Prof. Dr. Christian Drosten

Dr. Albrecht Gröner

Prof. Dr. Lutz Gürtler

Dr. Margarethe Heiden

PD Dr. Martin Hildebrandt

Prof. Dr. Dr. Bernd Jansen

Dr. Horst Klamm

Dr. Thomas Montag-Lessing

Dr. Ruth Offergeld

Prof. Dr. Rainer Seitz

Dr. Uwe Schlenkrich

Dr. Volkmar Schottstedt

Dr. Hannelore Willkommen

Prof. Dr. Carl-Heinz Wirsing von König

\section{References}

1 Balayan MS, Andjaparidze AG, Savinskaya SS, Ketiladze ES, Braginsky DM, Savinov AP, Poleschuk VF: Evidence for a virus in non-A, non-B hepatitis transmitted via the fecal-oral route. Intervirology 1983;20:23-31.

2 Reyes GR, Yarbough PO, Tam AW, Purdy MA, Huang CC, Kim JS, Bradley DW, Fry KE: Hepatitis E virus (HEV): the novel agent responsible for enterically transmitted non-A, non-B hepatitis. Gastroenterol Jpn 1991;26(suppl 3):142-147.

$\checkmark 3 \mathrm{Lu}$ L, Li C, Hagedorn CH: Phylogenetic analysis of global hepatitis E virus sequences. Genetic diversity, subtypes and zoonosis. Rev Med Virol 2006;16: 5-36.

4 Emerson SU, Purcell RH: Recombinant vaccines for hepatitis E. Trends Mol Med 2001;7:462-466.

$\checkmark 5$ Emerson SU, Arankalle VA, Purcell RH: Thermal stability of hepatitis E virus. J Infect Dis 2005;192. 930-933.

6 Tanaka T, Takahashi M, Kusano E, Okamoto H: Development and evaluation of an efficient cellculture system for hepatitis E virus. J Gen Virol 2007;88:903-911.

7 Previsani N, Lavanchy D: Hepatitis E - WHO/ CDS/CRS/EDC/2001.12. Geneva: World Health Organisation, Department of Communicable Disease Surveillance and Response, 2001. www.who. int/csr/disease/hepatitis/HepatitisE_whocdscsredc20 01_12.pdf.

8 Nanda SK, Ansari IH, Acharya SK, Jameel S, Panda SK: Protracted viremia during acute sporadic hepatitis $\mathrm{E}$ virus infection. Gastroenterology 1995;108:225-230.

$\checkmark 9$ Chauhan A, Jameel S, Dilawari JB, Chawla YK, Kaur U, Ganguly NK: Hepatitis E virus transmission to a volunteer. Lancet 1993;341:149-150.

10 Emerson SU, Purcell RH: Hepatitis E virus; in Knipe DM, et al. (eds): Fields Virology, 5th ed. Philadelphia, Lippincott Williams and Wilkins, 2007, p 78.
Purcell RH, Emerson SU: Animal models of hepatitis A and E. ILAR J 2001;42:161-177.

12 Zhang J, Ge SX, Huang GY, Li SW, He ZQ, Wang YB, Zheng YJ, Gu Y, Ng MH, Xia NS: Evaluation of antibody-based and nucleic acid-based assays for diagnosis of hepatitis $\mathrm{E}$ virus infection in a rhesus monkey model. J Med Virol 2003;71:518-526.

13 Hussaini SH, Skidmore SJ, Richardson P, Sherratt LM, Cooper BT, O'Grady JG: Severe hepatitis E infection during pregnancy. J Viral Hepat 1997;4: $51-54$.

14 Jilani N, Das BC, Husain SA, Baweja UK, Chattopadhya D, Gupta RK, Sardana S, Kar P: Hepatitis $\mathrm{E}$ virus infection and fulminant hepatic failure during pregnancy. J Gastroenterol Hepatol 2007;22: 676-682.

15 Mitsui T, Tsukamoto Y, Suzuki S, Yamazaki C, Masuko K, Tsuda F, Takahashi M, Tsatsralt-Od B, Nishizawa T, Okamoto H: Serological and molecular studies on subclinical hepatitis E virus infection using periodic serum samples obtained from healthy individuals. J Med Virol 2005;76:526-533.

16 Gotanda Y, Iwata A, Ohnuma H, Yoshikawa A, Mizoguchi H, Endo K, Takahashi M, Okamoto H: Ongoing subclinical infection of hepatitis $\mathrm{E}$ virus among blood donors with an elevated alanine aminotransferase level in Japan. J Med Virol 2007; 79:734-742. 17 Arankalle VA, Chobe LP: Retrospective analysis of
blood transfusion recipients: evidence for posttransfusion hepatitis E. Vox Sang 2000;79:72-74.

18 Khuroo MS, Kamili S, Yattoo GN: Hepatitis E virus infection may be transmitted through blood transfusions in an endemic area. J Gastroenterol Hepatol 2004;19:778-784.
19 Matsubayashi K, Nagaoka Y, Sakata H, Sato S, Fukai K, Kato T, Takahashi K, Mishiro S, Imai M, Takeda N, Ikeda H: Transfusion-transmitted hepatitis E caused by apparently indigenous hepatitis E virus strain in Hokkaido, Japan. Transfusion 2004; 44:934-940.

20 Boxall E, Herborn A, Kochethu G, Pratt G, Adams D, Ijaz S, Teo CG: Transfusion-transmitted hepatitis E in a 'nonhyperendemic' country. Transfus Med 2006;16:79-83.

21 Colson P, Coze C, Gallian P, Henry M, De Micco P, Tamalet C: Transfusion-associated hepatitis E, France. Emerg Infect Dis 2007;13:648-649.

22 Meng XJ, Dea S, Engle RE, Friendship R, Lyoo YS Sirinarumitr T, Urairong K, Wang D, Wong D, Yoo D, Zhang Y, Purcell RH, Emerson SU: Prevalence of antibodies to the hepatitis $\mathrm{E}$ virus in pigs from countries where hepatitis $\mathrm{E}$ is common or is rare in the human population. J Med Virol 1999;59: 297-302.

23 Peron JM, Mansuy JM, Izopet J, Vinel JP: Hepatitis E virus: An emerging disease. Sante 2006;16: 239-243.

24 Herremans M, Duizer E, Jusic E, Koopmans MP: Detection of hepatitis E virus-specific immunoglobulin A in patients infected with hepatitis $\mathrm{E}$ virus genotype 1 or 3. Clin Vaccine Immunol 2007; 14:276-280.

25 Okamoto H: Genetic variability and evolution of hepatitis E virus. Virus Res 2007;127:216-228.

26 Meng XJ, Purcell RH, Halbur PG, Lehman JR, Webb DM, Tsareva TS, Haynes JS, Thacker BJ, Emerson SU: A novel virus in swine is closely related to the human hepatitis E virus. Proc Natl Acad Sci U S A 1997;94:9860-9865.

27 Meng XJ: Novel strains of hepatitis E virus identified from humans and other animal species: is hepatitis E a zoonosis? J Hepatol 2000;33:842-845. 
28 Matsuda H, Okada K, Takahashi K, Mishiro S: Severe hepatitis $\mathrm{E}$ virus infection after ingestion of uncooked liver from a wild boar. J Infect Dis 2003; 188:944.

29 Feagins AR, Opriessnig T, Guenette DK, Halbur PG, Meng XJ: Detection and characterization of infectious hepatitis E virus from commercial pig livers sold in local grocery stores in the USA. J Gen Virol 2007;88:912-917.

30 Seminati C, Mateu E, Peralta B, de Deus N, Martin $\mathrm{M}$ : Distribution of hepatitis $\mathrm{E}$ virus infection and its prevalence in pigs on commercial farms in Spain. Vet J 2007:DOI 10.1016/j.tvjl.2006.11.018.

-31 Rutjes SA, Lodder WJ, Bouwknegt M, de Roda Husman AM: Increased hepatitis E virus prevalence on Dutch pig farms from 33 to $55 \%$ by using appropriate internal quality controls for RT-PCR. J Virol Methods 2007;143:112-116.

-32 Banks M, Bendall R, Grierson S, Heath G, Mitchell J, Dalton H: Human and porcine hepatitis E virus strains, United Kingdom. Emerg Infect Dis 2004;10: 953-955.

33 Dalton HR, Thurairajah PH, Fellows HJ, Hussaini HS, Mitchell J, Bendall R, Banks M, Ijaz S, Teo CG, Levine DF: Autochthonous hepatitis E in southwest England. J Viral Hepat 2007;14:304-309.

-34 Mateos ML, Camarero C, Lasa E, Teruel JL, Mir N, Baquero F: Hepatitis E virus: relevance in blood donors and risk groups. Vox Sang 1999;76:78-80.

- 35 Boutrouille A, Bakkali-Kassimi L, Cruciere C, Pavio N: Prevalence of anti-hepatitis E virus antibodies in French blood donors. J Clin Microbiol 2007;45:2009-2010.

36 Meng XJ, Wiseman B, Elvinger F, Guenette DK, Toth TE, Engle RE, Emerson SU, Purcell RH: Prevalence of antibodies to hepatitis E virus in veterinarians working with swine and in normal blood donors in the United States and other countries. J Clin Microbiol 2002;40:117-122.

37 Olsen B, Axelsson-Olsson D, Thelin A, Weiland O: Unexpected high prevalence of IgG-antibodies to hepatitis E virus in Swedish pig farmers and con trols. Scand J Infect Dis 2006;38:55-58.

38 Clemente-Casares P, Pina S, Buti M, Jardi R, Martin M, Bofill-Mas S, Girones R: Hepatitis E virus epidemiology in industrialized countries. Emerg Infect Dis 2003;9:448-454.

-39 Trautwein C, Kiral G, Tillmann HL, Witteler H, Michel G, Manns MP: Risk factors and prevalence of hepatitis $\mathrm{E}$ in German immigrants from the former Soviet Union. J Med Virol 1995;45:429-434.

40 Teich N, Tannapfel A, Ammon A, Ruf BR, van der Poe WHM, Mössner J, Liebert UG: Sporadic acute hepatitis E in Germany: an underdiagnosed phenomenon? Z Gastroenterol 2003;41:419-423.
41 Preiss JC, Plentz A, Engelmann E, Schneider T, Jilg W, Zeitz M, Duchmann R: Autochthonous hepatitis E virus infection in Germany with sequence similarities to other European isolates. Infection 2006; 34:173-175.

42 Ahn J, Rayamajhi N, Gyun Kang S, Sang Yoo H: Comparison of real-time reverse transcriptase-polymerase chain reaction and nested or commercial reverse transcriptase-polymerase chain reaction for the detection of hepatitis E virus particle in human serum. Diagn Microbiol Infect Dis 2006; 56:269-274.

43 Enouf V, Dos Reis G, Guthmann JP, Guerin PJ, Caron M, Marechal V, Nicand E: Validation of single real-time TaqMan PCR assay for the detection and quantitation of four major genotypes of hepatitis E virus in clinical specimens. J Med Virol 2006; 78:1076-1082.

44 Inoue J, Takahashi M, Yazaki Y, Tsuda F, Okamoto $\mathrm{H}$ : Development and validation of an improved RT-PCR assay with nested universal primers for detection of hepatitis $\mathrm{E}$ virus strains with significant sequence divergence. J Virol Methods 2006;137: 325-333.

45 Zhang F, Li X, Li Z, Harrison TJ, Chong H, Qiao S, Huang W, Zhang H, Zhuang H, Wang Y: Detection of HEV antigen as a novel marker for the diagnosis of hepatitis E. J Med Virol 2006;78:1441-1448.

46 Tian DY, Chen Y, Xia NS: Significance of serum IgA in patients with acute hepatitis E virus infection. World J Gastroenterol 2006;12:3919-3923.

47 Fukuda S, Sunaga J, Saito N, Fujimura K, Itoh Y, Sasaki M, Tsuda F, Takahashi M, Nishizawa T, Okamoto H: Prevalence of antibodies to hepatitis E virus among Japanese blood donors: identification of three blood donors infected with a genotype 3 hepatitis E virus. J Med Virol 2004;73:554-561.

48 Arankalle VA, Chobe LP: Hepatitis E virus: can it be transmitted parenterally? J Viral Hepat 1999;6: 161-164.

49 Zaaijer HL, Mauser-Bunschoten EP, ten Veen JH, Kapprell HP, Kok M, van den Berg HM, Lelie PN: Hepatitis E virus antibodies among patients with hemophilia, blood donors, and hepatitis patients. J Med Virol 1995;46:244-246

50 Ritter A, Witteler H, Simpson B, Chiewsilp P, Hinde B, Vidler J, Lemair L, Castella D: A multicentre study of HEV seropositivity in random blood donors. J Hepatol 1993;18(suppl 1):25.

51 Bekanntmachung der Richtlinien zur Gewinnung von Blut und Blutbestandteilen und zur Anwendung von Blutprodukten (Hämotherapie) gemäß $\S \S 12$ und 18 des Transfusionsgesetzes (TFG) (Novelle 2005) vom 19. September 2005. Bundesanzeiger 2005, Nr. 209a, 05.11.2005.
52 Bekanntmachung der Richtlinien zur Gewinnung von Blut und Blutbestandteilen und zur Anwendung von Blutprodukten (Hämotherapie) gemäß $\S \S 12$ und 18 des Transfusionsgesetzes (TFG) (Änderungen und Ergänzungen 2007) vom 17. April 2007. Bundesanzeiger 2007, Nr. 92, 19.05.2007, S. 5075 .

53 Burger R, Gerlich W, Gürtler L, Heiden M, Hitzler W, Jansen B, Lefèvre H, Löwer J, Ludwig WD, Montag-Lessing T, Neumann R, Paessens A, Pauli G, Seitz R, Schlenkrich U, Werner E, Willkommen H: Hepatitis A virus. Infus Ther Transfus Med 2001; 28:354-360.

54 Mitsui T, Tsukamoto Y, Yamazaki C, Masuko K, Tsuda F, Takahashi M, Nishizawa T, Okamoto H: Prevalence of hepatitis E virus infection among hemodialysis patients in Japan: evidence for infection with a genotype $3 \mathrm{HEV}$ by blood transfusion. J Med Virol 2004;74:563-572.

55 Barzilai A, Schulman S, Karetnyi YV, Favorov MO, Levin E, Mendelson E, Weiss P, Fields HA, Varon D, Martinowitz U: Hepatitis E virus infection in hemophiliacs. J Med Virol 1995;46:153-156.

56 Buti M, Jardi R, Cotrina M, Rodriguez-Frias F, Troonen H, Viladomiu L, Esteban JI, Esteban R, Guardia J: Hepatitis E virus infection in acute hepatitis in Spain. J Virol Methods 1995;55:49-54.

57 Tamura A, Shimizu YK, Tanaka T, Kuroda K, Arakawa Y, Takahashi K, Mishiro M, Shimizu K, Moriyama M: Persistent infection of hepatitis E virus transmitted by blood transfusion in a patient with T-cell lymphoma. Hepatol Res 2007;37: 113-120.

58 Pillot J, Turkoglu S, Dubreuil P, Cosson A, Lemaigre G, Meng J, Lazizi Y: Cross-reactive immunity against different strains of the hepatitis $\mathrm{E}$ virus transferable by simian and human sera. C R Acad Sci III 1995;318:1059-1064.

59 Worm HC, Wirnsberger G: Hepatitis E vaccines: progress and prospects. Drugs 2004;64:1517-1531.

60 Maloney BJ, Takeda N, Suzaki Y, Ami Y, Li TC, Miyamura T, Arntzen CJ, Mason HS: Challenges in creating a vaccine to prevent hepatitis E. Vaccine 2005;23:1870-1874.

61 Deshmukh TM, Lole KS, Tripathy AS, Arankalle VA: Immunogenicity of candidate hepatitis $\mathrm{E}$ virus DNA vaccine expressing complete and truncated ORF2 in mice. Vaccine 2007;25:4350-4360.

62 Dong C, Dai X, Meng JH: The first experimental study on a candidate combined vaccine against hepatitis A and hepatitis E. Vaccine 2007;25: $1662-1668$.

63 Shrestha MP, Scott RM, Joshi DM, Mammen MP, Thapa GB, Thapa N, Myint KS, Fourneau M, Kuschner RA, Shrestha SK, David MP, Seriwatana J, Vaughn DW, Safary A, Endy TP, Innis BL: Safety and efficacy of a recombinant hepatitis E vaccine. N Engl J Med 2007;356:895-903. 